\title{
The theory of endogenous money and the LM schedule: prelude to a reconstruction of ISLM*
}

\author{
A teoria da moeda endógena e o cronograma LM: \\ abertura para uma reconstrução do modelo IS-LM
}

THOMAS I. PALLEY ${ }^{1}$

\begin{abstract}
RESUMO: A moeda está no centro da macroeconomia e a oferta de moeda é portanto central para a teoria macroeconômica. Este trabalho apresenta a teoria pós-keynesiana da oferta de moeda endógena e mostra como ela é fundamentalmente diferente da teoria da oferta de moeda convencional. A abordagem convencional se baseia no multiplicador da moeda, e o crédito bancário permanece invisível. O artigo enfatiza a versão estruturalista da teoria pós-keynesiana que mantém a teoria de Keynes da preferência pela liquidez das taxas de juro de longo prazo e também reconhece que os bancos estão sujeitos a restrições financeiras que limitam suas atividades de empréstimo. O documento, em seguida, mostra como derivar o cronograma LM em uma economia monetária endógena, que é um prelúdio necessário para reconstruir o modelo ISLM.
\end{abstract}

PALAVRAS-CHAVE: dinheiro endógeno; estruturalismo; horizontalismo; cronograma LM modelo ISLM.

ABSTRACT: Money is at the center of macroeconomics, which makes understanding the money supply central for macroeconomic theory. This paper presents the Post Keynesian theory of endogenous money supply and shows how it is fundamentally different from the conventional money supply theory. The conventional approach relies on the money multiplier and bank lending is invisible. Post Keynesian theory discards the money multiplier and focuses on bank lending which drives money creation. The paper emphasizes the structuralist version of Post Keynesian theory which retains Keynes' liquidity preference theory of long term interest rates and also recognizes banks are subject to financial constraints that limit their lending activities. The paper then shows how to derive the LM schedule in an endogenous money economy, which is a necessary prelude to reconstructing the ISLM model.

KEYWORDS: endogenous money, structuralism, horizontalism, LM schedule, ISLM model. JEL Classification: E51; E52; E58.

\footnotetext{
"The author thanks two anonymous referees for their very helpful comments. Any remaining errors are the responsibility of the author.

${ }^{1}$ Independent economist, Washington, DC, USA, e-mail: mail@thomaspalley.com. Submitted 30/ March/2016; approved: 19/August/2016.
} 


\section{INTRODUCTION}

Money is at the center of macroeconomics and understanding the determination of the money supply is therefore critical for macroeconomic theory. That explains the Post Keynesian focus on the theory of endogenous money. This paper shows how Post Keynesian endogenous money theory is fundamentally different from conventional money multiplier theory. It then derives the LM schedule for an endogenous money economy using the structuralist approach to endogenous money which emphasizes the significance of portfolio choices and microeconomic constraints on individual banking firms. The endogenous money LM schedule is a necessary prelude for reconstruction of the ISLM model.

\section{KEYNESIAN MONETARY THEORY RECONSIDERED}

Money is at the center of Keynesian macroeconomics, yet Keynes (1936) paid little attention to the determination of the money supply and treated it as exogenous. That treatment has been the source of much confusion in macroeconomics. It is therefore useful to begin with a little history of economic thought that helps understand the theoretical flaw which is at the core of existing mainstream theory of the money supply.

The starting point is Keynes' (1936) liquidity preference theory of interest rates which represents one of the critical innovations of his General Theory. Keynes' General Theory pays great attention to the significance and specification of money demand (chapter 15) and the properties and implications of money (chapter 17). However, it pays almost no attention to the issue of money supply which is described as being essentially exogenous, having a zero elasticity of production:

"The first characteristic which tends toward the above conclusion is the fact that money has, both in the long and the short period, a zero, or at any rate a very small, elasticity of production, so far as the power of private enterprise is concerned, as distinct from the monetary authority; (Keynes, 1936, p. 230)".

Keynes' model of the money supply and interest rate determination is given by the following three equations:

(1) $M^{s}=M / P$

(2) $\mathrm{M}^{\mathrm{d}}=\mathrm{M}(\mathrm{i}, \mathrm{y}, \mathrm{X}) \quad \mathrm{M}_{\mathrm{i}}<0, \mathrm{M}_{\mathrm{y}}>0, \mathrm{M}_{\mathrm{X}}>0$

(3) $M^{s}=M^{d}$

$\mathrm{M}^{\mathrm{s}}$ = real money supply, $\mathrm{M}=$ exogenous nominal money supply, $\mathrm{P}=$ general price level, $\mathrm{M}^{\mathrm{d}}$ = real money demand, $\mathrm{i}=$ nominal interest rate on bonds, $\mathrm{y}=$ real income, $\mathrm{X}=$ state of bearishness. Equation (1) determines the real money supply. 
Equation (2) determines aggregate real money demand which consists of the demand for transactions and speculative money balances, and is a negative function of the nominal interest rate and a positive function of real income and the state of bearishness. Equation (3) is the money market clearing condition. For the rest of the paper the price level is assumed fixed as the period of analysis is the very short term.

Figure 1 provides a simple graphical analogue of the model. According to Keynes' theory of interest rate determination, as described in chapter 13 of The General Theory, the nominal interest on bonds adjusts to equilibrate money supply and money demand. The interest rate has nothing to do with being a "reward for waiting". Instead, it is the reward for bearing risk plus the reward for "not hoarding" by giving up liquidity and holding bonds.

\section{Figure 1: Keynes' General Theory model of interest rate determination}

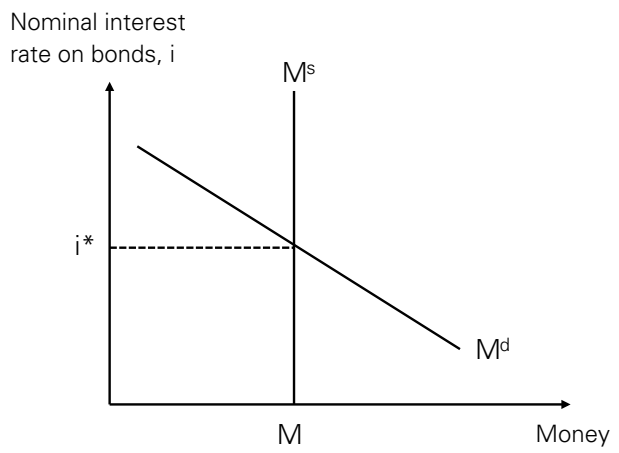

In The General Theory the money supply is exogenous and any endogeneity of "monetary capacity" comes exclusively from money demand. In chapter 15 Keynes (1936, p. 199) decomposes money demand into transactions and speculative demands, with the transactions demand being a positive function of income and speculative demand being a negative function of the nominal interest, as follows:

(4) $\mathrm{M}^{\mathrm{d}}=\mathrm{M}_{1}(\mathrm{y})+\mathrm{M}_{2}(\mathrm{i}) \quad \mathrm{M}_{1, \mathrm{y}}>0, \mathrm{M}_{2, \mathrm{i}}<0$

$\mathrm{M}_{1}=$ transactions demand, $\mathrm{M}_{2}=$ speculative demand. Thus, in response to higher income, the system's ability to accommodate more transacting comes from higher interest rates that induce agents to economize on speculative money hoards, which releases money for transactions purposes.

In The Treatise on Money Keynes (1930) emphasized another mechanism of endogenous monetary capacity, which was release of money from the financial sector to the real sector (Palley, 1998). Here, the mechanism is reallocation of money balances across sectors, but the overall money supply remains exogenously fixed.

Neo-Keynesian macroeconomics introduced the money multiplier model which is given by: 
(5) $\mathrm{H}^{\mathrm{s}}=\mathrm{H} / \mathrm{P}$

(6) $\mathrm{M}^{\mathrm{s}}=\mathrm{m}(\mathrm{i}, \mathrm{k}) \mathrm{H}^{\mathrm{s}}$

$$
\begin{aligned}
& \mathrm{m}_{\mathrm{i}}>0, \mathrm{~m}_{\mathrm{k}}<0 \\
& \mathrm{M}_{\mathrm{i}}<0, \mathrm{M}_{\mathrm{y}}>0, \mathrm{M}_{\mathrm{X}}>0
\end{aligned}
$$

(7) $M^{d}=M(i, y, X)$

(8) $\mathrm{M}^{\mathrm{s}}=\mathrm{M}^{\mathrm{d}}$

$\mathrm{H}^{\mathrm{s}}$ = real supply of outside money (liabilities of the central bank), $\mathrm{H}=$ exogenous nominal outside money supply, $\mathrm{m}()=$. money multiplier, $\mathrm{k}=$ reserve requirement ratio for inside money (bank deposits). Equation (5) determines the supply of outside money, while equation (6) determines the supply of inside money.

There are several features to note compared to Keynes' General Theory model. First, there is now a distinction between outside money and inside money. Outside money refers to liabilities of the central bank. Inside money refers to bank deposits created by the banking system. Second, outside money is exogenous and under the control of the central bank. Inside money is endogenous and created by the banking system through the money multiplier mechanism. The overall money supply is therefore endogenous and the element of exogeneity is pushed into the background. Third, the inside money supply depends jointly on the volume of high powered money and the magnitude of the money multiplier. The elasticity of the inside money supply depends on the sensitivity of the money multiplier to the interest rate. Fourth, the magnitude of the money multiplier also depends negatively on the size of reserve requirements. A higher reserve requirement means banks must retain as reserves more of each deposit they receive, reducing the amount they have available to lend out and create additional deposits.

The model is illustrated in Figure 2 that shows the neo-Keynesian construction of the money market. The money supply is now a positive function of the nominal interest rate on bonds, and the nominal interest rate adjusts to equalize supply and demand for real money balances.

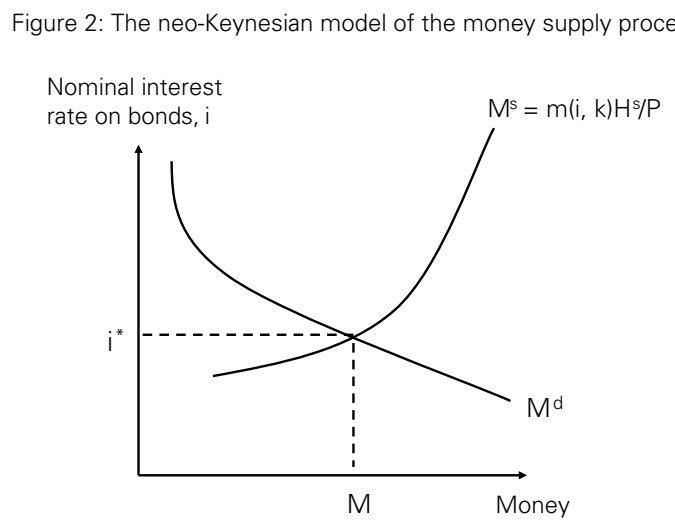

The economic logic of the positively sloped money supply function is that higher interest rates induce agents to economize on use of reserves, freeing up reserves to support deposits created by the banking system. The bond rate is the opportunity cost of holding high-powered money balances. A higher opportunity 
cost gets agents (households, firms, and financial institutions) to economize on high-powered money balances, enabling the existing stock to support a larger inside money supply. This logic is similar to Keynes' logic regarding endogenous monetary capacity and the interest rate remains the reward for not hoarding. NeoKeynesian money supply theory is therefore fully consistent with The General Theory. The only difference is the introduction of an endogenous inside money supply, the explanation for which is the theory of the money multiplier.

For the last three decades, since the failure of the monetarist experiments in the early 1980 s, central banks have explicitly targeted nominal interest rates. The rationale for this policy is rooted in Poole's (1970) seminal paper which shows that when financial disturbances predominate, optimal policy should target the nominal interest rate to prevent those disturbances from spilling into the real economy. ${ }^{2}$

Nominal interest rate targeting transforms the representation of the money market in the conventional money multiplier model, as shown in Figure 3. Now, the money supply schedule is horizontal at the target interest rate. The logic is the monetary authority supplies or draws down liquidity to keep the interest rate at the target.

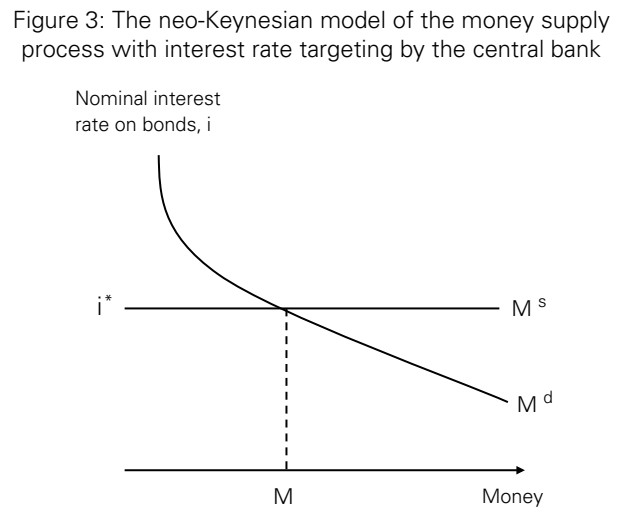

From a policy perspective, interest rate targeting has undoubtedly been desirable. However, from a theoretical perspective it has muddied the water and made it more difficult to present the Post Keynesian theory of endogenous money. That is because it removes the remaining element of exogeneity regarding outside money balances, thereby removing the stark difference with Post Keynesian theory and creating observational equivalence. That has crowded out space for the Post Keynesian model even though its analysis (as shown below) is significantly different, making it more difficult to establish a correct understanding of the money supply process.

With regard to particulars, credit remains invisible and apparently irrelevant for the money supply process in neo-Keynesian representations of interest rate targeting

\footnotetext{
${ }^{2}$ Poole (1970) develops his argument in a neo-Keynesian stochastic ISLM model. Sargent and Wallace (1975) show that this argument carries over to a rational expectations new classical model, but now there is additional need to have policy anchor the future expected inflation rate.
} 
regimes. That contributes to misunderstanding of how monetary policy works and neglect of credit market policies for stabilizing and managing the economy.

\section{AGAINST MONETARISM: THE ORIGINS OF POST KEYNESIAN ENDOGENOUS MONEY THEORY}

The above brief history provides a synopsis of conventional money supply theory. This section turns to Post Keynesian money supply theory. The initial impulse for its development was as a response to monetarism, and Nicholas Kaldor $(1970,1982)$ was the seminal pioneer contributor.

Monetarism emerged as an important macroeconomic doctrine in the 1960s and its main theoretical claims were (Palley, 1993, 2014a):

1) The money supply is exogenous and controlled by central banks.

2) Money is all that matters and fiscal policy is ineffective unless it is money financed.

3) Inflation is caused exclusively by money supply growth.

4) Central banks should adopt a simple money supply growth rule to promote economic stability.

Post Keynesians rejected all of these claims and the roots of the Post Keynesian endogenous money theory lie in opposition to monetarism, both as theory and as policy prescription. Neo-Keynesians also vigorously opposed monetarism (see Palley 2014a for a survey and summary), but their critique was conducted using the conventional money multiplier theory of money supply determination. Post Keynesians sought a deeper critique of monetarism based on its theory of the money supply. The cornerstone of monetarism is the claim that the central bank controls the money supply, thereby rendering the money supply exogenous. Post Keynesians sought to demolish that cornerstone.

\section{THE THEORY OF ENDOGENOUS MONEY}

Unfortunately, the Post Keynesian approach has been subject to internal controversy that has created an additional source of difficulty in gaining recognition for the theory. Figure 4 divides the Post Keynesian approach to money supply determination into "horizontalists/accommodationists" and "structuralists. The "horizontalist" label was introduced by Moore (1988) in his seminal statement of the theory of endogenous money. The terminology and distinction between accommodationists and structuralists was introduced by Pollin (1991) who identified some significant differences that initially separated the two approaches. Figure 4 also introduces a distinction between "early" horizontalism and "later" horizontalism. That distinction is useful for understanding the voluminous and confusing debate between horizontalists and structuralists, as well as the subsequent convergence that has taken place. 
Figure 4: Competing approaches in the Post Keynesian theory of endogenous money supply

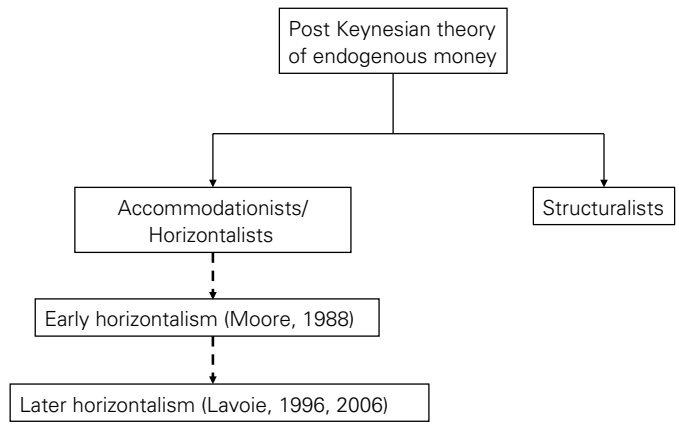

Both horizontalists and structuralists subscribe to the core Post Keynesian proposition that bank lending drives the money, rendering the latter endogenous. However, as argued below, early horizontalists (see Moore, 1988) tended to oversimplify and mistakenly discard enduring insights from Keynesian monetary theory, causing significant discord and unnecessary confusion among Post Keynesians. For instance, Moore rejected the liquidity preference theory of interest rates, the existence of money demand, and the endogeneity of interest rates. Later horizontalists (see Lavoie, 1996, 2006) fully accept liquidity preference theory and the endogeneity of interest rates, contributing to substantial convergence of horizontalism and structuralism. That convergence is constructive, but it has also obscured important microeconomic differences regarding constraints on banking firms that still remain. ${ }^{3}$

\section{HORIZONTALISM}

Because of its greater simplicity, it is worth beginning with Moore's (1988) early horizontalist description of money supply determination as it clearly shows

\footnotetext{
${ }^{3}$ Palley (2013a, 2014b) provides a comprehensive statement of the structuralist critique of early horizontalism. The critique consists of the following four charges: (1) Failure to take account of liquidity preference effects in the determination of interest rates. (2) Failure to take account of general equilibrium interactions across different financial markets. (3) Failure to recognize that "individual" banks may be financially constrained by their balance sheets. (4) Failure to recognize that the overall financial system may be financially constrained by the central bank's policy reaction function, knowledge of which will be incorporated within the behavior of individual banks. Later horizontalists have incorporated points (1) and (2) but not (3) and (4). Early structuralist critiques of horizontalism (Palley, 1991) slightly misstated the last two critiques by focusing on the slope of the loan supply schedule. In fact, the issue is whether individual banks are financially constrained. Horizontalists/accommodationists say they are not: structuralists say they are.
} 
the essential mechanism of endogenous money. That early horizontalist approach is captured by the following six equation model (Palley, 1994):

(9) $i_{L}=[1+m] i_{F}$

(10) $\mathrm{L}^{\mathrm{d}}=\mathrm{L}\left(\mathrm{i}_{\mathrm{L}}, \ldots \ldots\right) \quad \mathrm{L}_{\mathrm{iL}}<0$

(11) $\mathrm{L}^{\mathrm{s}}=\mathrm{L}^{\mathrm{d}}$

(12) $L^{s}+R=M+E$

(13) $\mathrm{R}=\mathrm{kM}$

$0<\mathrm{k}<1$

(14) $\mathrm{H}=\mathrm{R}$

$\mathrm{i}_{\mathrm{L}}=$ loan rate, $\mathrm{m}=$ bank mark-up, $\mathrm{i}_{\mathrm{F}}=$ money market rate set by policy, $\mathrm{L}^{\mathrm{d}}=$ loan demand, $\mathrm{L}^{\mathrm{s}}=$ loan supply, $\mathrm{R}=$ required reserves, $\mathrm{E}=$ bank equity, $\mathrm{k}=$ required reserve ratio, $\mathrm{H}=$ exogenous nominal outside money.

Equation (9) determines banks' loan rate as a mark-up over the money market rate which is set by policymakers. The money market rate represents the wholesale cost of finance to banks. Equation (10) is the loan demand function. Equation (11) is the loan market clearing condition and has loan supply equal to loan demand. Equation (12) is the banking sector's balance sheet. Assets consist of loans and reserves, while liabilities consist of deposits and bank equity. Equation (13) determines banks' holdings of reserves which are equal to required reserves. Lastly, equation (14) determines the supply of monetary base which is equal to bank reserves.

As shown in Palley (1994) the basic model is easily expanded to incorporate bank excess reserves, time deposits, and currency held by the non-bank public. Adding these features leaves the model's logic unchanged. These features are not included in order to keep the analysis as simple as possible so as to facilitate comparison of approaches.

The solutions for the model are given by:

(15) $\mathrm{L}=\mathrm{L}\left([1+\mathrm{m}] \mathrm{i}_{\mathrm{F}}, \ldots\right)$

(16) $\mathrm{M}=[\mathrm{L}-\mathrm{E}] /[1-\mathrm{k}]$

(17) $\mathrm{H}=\mathrm{k}[\mathrm{L}-\mathrm{E}] /[1-\mathrm{k}]$

The model is illustrated in Figure 5. The supply of monetary base (northwest quadrant) is horizontal at the policy determined money market interest rate. The loan supply schedule (northeast quadrant) is horizontal at the loan rate which is a mark-up over the policy rate. Banks satisfy all loan demand forthcoming at that rate. They are price-setters and quantity-takers. Bank lending determines deposit creation and thereby determines the money supply. The central bank then adjusts the supply of reserves to back deposits created by bank lending. It does so by buying bonds from or selling bonds to the non-bank public, thereby injecting or draining reserves according to the needs of banks based on their lending activity. 


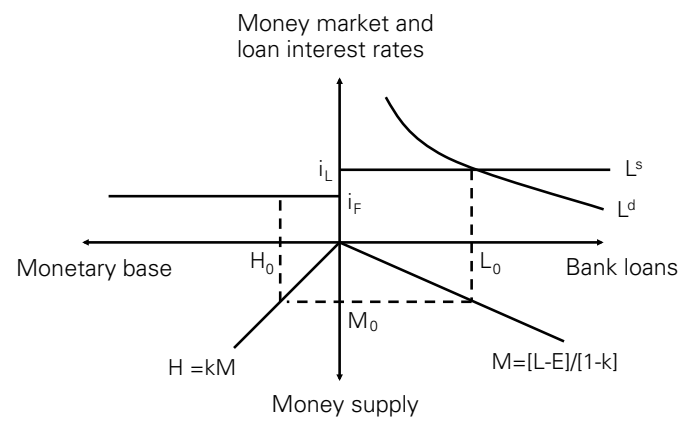

There are several important features about the simple horizontalist model. First and foremost, loans create deposits. This is a completely different description of the money supply process compared to the money multiplier story in the neoKeynesian model with interest rate targeting story in which the supply of reserves is also horizontal.

Second, there is a money multiplier as shown in the southwest quadrant of Figure 5 since the money supply is given by

(18) $\mathrm{M}=\mathrm{H} / \mathrm{k}$

However, the money multiplier is an after the fact phenomenon rather than being a driver of money supply creation. These observational equivalences explain why it has been so difficult for the Post Keynesian approach to gain attention, despite thirty years of writing.

Third, the determination of the money supply really reflects a loan multiplier (Coghlan, 1978), which is shown in the southeast quadrant of Figure 5 and given by

(19) $\mathrm{M}=[\mathrm{L}-\mathrm{E}] /[1-\mathrm{k}]$

There is no money supply schedule per se. Instead, money is created by bank lending.

The above model is the simplest version of the horizontalist model. It can easily be refined to have an upward sloping loan supply schedule (Palley, 1994, 2013a). One reason is that banks raise their mark-with the volume of lending to reflect possible increased risks. A second reason is that the monetary authority raises its target interest rate as the money supply or volume of lending increases, in which case the outside money (reserve) supply and loan supply schedules are no longer horizontal. If the loan supply is positively sloped for reasons just discussed, then the money supply will show positive correlation with the loan rate, making it look as if there is a money supply function that is a positive function of the interest rate. 


\section{STRUCTURALISM}

Structuralism represents the second branch of the Post Keynesian approach to the money supply. Like horizontalism, it also embodies the core logic of loans creating deposits. However, it remedies important omissions and oversights in the early horizontalist model. In particular, there are two critical failings in that model. The first concerns the exogeneity of long-term interest rates. The second concerns the absence of money demand. These two failings are related and the structuralist model remedies them. ${ }^{4}$

The structuralist model (Palley, 1987/88, 1994, 2013) addresses both of these failings by introducing money demand and restoring Keynes' theory of long-term interest rate determination. The equations of the model are given by:
(20) $\mathrm{M}^{\mathrm{d}}=\mathrm{M}\left(\mathrm{i}_{\mathrm{M}}, \mathrm{i}_{\mathrm{B}}, \mathrm{y}, \mathrm{X}, \mathrm{Z}\right)$
$\mathrm{M}_{\mathrm{iM}}>0, \mathrm{M}_{\mathrm{iB}}<0, \mathrm{M}_{\mathrm{y}}>0, \mathrm{M}_{\mathrm{x}}>0, \mathrm{M}_{\mathrm{z}}>0$
(21) $\mathrm{L}=\mathrm{L}\left(\mathrm{i}_{\mathrm{L}}, \mathrm{y}, \mathrm{A}\right)$
$\mathrm{L}_{\mathrm{iL}}<0, \mathrm{~L}_{\mathrm{y}-\mathrm{T}}>0, \mathrm{~L}_{\mathrm{A}}>0$
(22) $\mathrm{L}+\mathrm{kM}=\mathrm{M}+\mathrm{B}+\mathrm{E}$
(23) $\mathrm{i}_{\mathrm{L}}=[1+\mathrm{m}(\mathrm{L})] \mathrm{i}_{\mathrm{F}}+\mathrm{c}$
$\mathrm{m}_{\mathrm{L}} \geq 0$
(24) $\mathrm{i}_{\mathrm{M}}=[1-\mathrm{k}] \mathrm{i}_{\mathrm{F}}-\mathrm{z}$
(25) $\mathrm{H}=\mathrm{N}+\mathrm{B}=\mathrm{kM}$

$\mathrm{M}=$ demand for real money balances (bank deposits), $\mathrm{i}_{\mathrm{M}}=$ deposit interest rate, $\mathrm{i}_{\mathrm{B}}=$ bond interest rate, $\mathrm{y}=$ real income, $\mathrm{X}=$ vector of expected future interest rates, $\mathrm{Z}=$ state of bearishness (liquidity preference shift factor), $\mathrm{H}=$ supply of real high powered money, $\mathrm{L}=$ real loan demand, $\mathrm{k}=$ reserve requirement on deposits, $\mathrm{N}=$ non-borrowed reserves, $\mathrm{B}=$ borrowed reserves, $\mathrm{i}_{\mathrm{L}}=$ loan interest rate, $\mathrm{c}=$ banks' cost per dollar of making loans, and $\mathrm{z}=$ cost per dollar of supplying deposits.

Equation (20) is the demand for bank deposits which depends positively on the deposit rate, income, expectations of future short term interest rates, and the state of bearishness, and negatively on the bond rate. Equation (21) defines real loan demand which is a negative function of the loan rate and a positive function of income. Equation (22) is the banking sector's balance sheet identity. Assets consist of loans $(\mathrm{L})$ and required reserves $(\mathrm{kM})$ : liabilities consist of deposits $(\mathrm{M})$ and borrowed reserves (B) which banks borrow at the money market rate. When the banking system is short of reserves, banks borrow from the central bank. ${ }^{5}$ Equation (23) determines the loan rate as a mark-up over the money market cost of funds. The mark-up can be a positive function of the volume of lending if default risks rise with lending due to credit quality deterioration. Equation (24) deter-

\footnotetext{
${ }^{4}$ Over time, horizontalist-accommodationsts have responded to structuralist critiques. For instance, Lavoie $(1996,2006)$ incorporates money demand into the accommodationist model. That remedies flaws in Moore's (1988) model, but it does not address other structuralist critiques regarding banks being balance sheet constrained in their lending activities.

5. This is the simplest way of modeling how banks get hold of needed reserves. A more complicated model involves modeling the bond supply and having the central bank conduct open market operations to supply reserves and thereby maintain the policy rate at its target level.
} 
mines the deposit rate which is a mark-down over the money market cost of funds that takes account of the costs of administering deposits $(\mathrm{z})$ and holding reserve requirements $(\mathrm{k})$. Equation (25) is the money market equilibrium condition in which the supply of high-powered money equals demand. The demand for highpowered money consists of required reserves.

Rearranging equation (22) and using equations (20), (21), (23), and (24) yields:

(26) $\mathrm{M}\left([1-\mathrm{k}] \mathrm{i}_{\mathrm{F}}-\mathrm{z}, \mathrm{i}_{\mathrm{B}}, \mathrm{y}, \mathrm{X}, \mathrm{Z}\right)=\left[\mathrm{L}\left([1+\mathrm{m}(\mathrm{L})] \mathrm{i}_{\mathrm{F}}+\mathrm{c}, \mathrm{y}, \mathrm{A}\right)-\mathrm{B}-\mathrm{E}\right] /[1-\mathrm{k}]$

Substituting equation (26) into equation (25) yields:

(27) $\mathrm{H}=\mathrm{k}\left[\mathrm{L}\left(\mathrm{i}_{\mathrm{F}}+\mathrm{c}, \mathrm{y}, \mathrm{A}\right)-\mathrm{B}-\mathrm{E}\right] /[1-\mathrm{k}]$

Equation (26) shows that the deposit money supply is determined by bank lending.

The model is illustrated in Figure 6. The northeast panel shows the loan demand and deposit supply schedules. The level of bank lending is determined by the loan rate, which is a mark-up over the money market rate. The deposit supply schedule is derived from loan demand via the banking sector's balance sheet constraint, reflecting the endogenous money process whereby loans create deposits. The southeast panel shows the demand for money balances (deposits) and determines the bond rate. Given the supply of deposit money created by banks, the bond rate must adjust so that agents willingly hold these deposits. The northwest panel determines the supply of high-powered money which consists of borrowed and non-borrowed reserves. The borrowed component is $\mathrm{H}^{*}-\mathrm{N}$. The monetary authority targets its policy interest rate and then supplies reserves to banks via borrowed reserves on an as needed basis. ${ }^{6}$

Figure 6: Determination of the supply of high-powered money, the money supply, bank lending, and interest rates

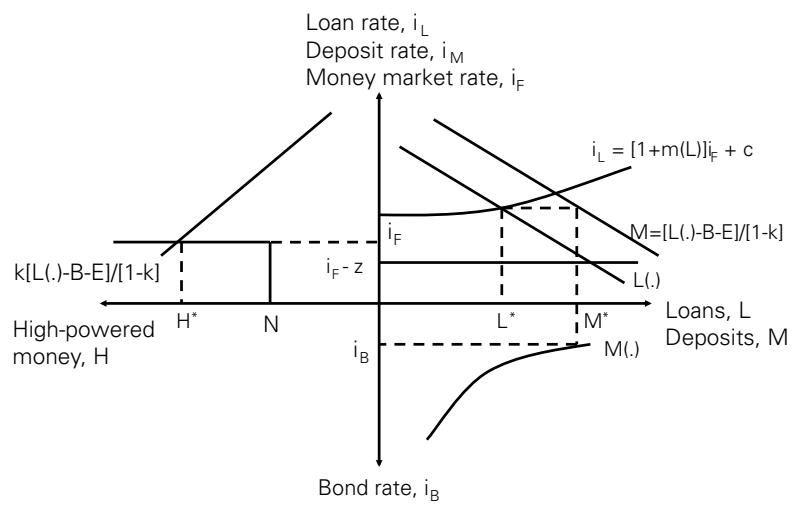

\footnotetext{
${ }^{6}$ As shown in Palley (2014c), the model is also applicable to an excess reserve situation in which case banks deposit their excess reserves with the central bank.
} 
There are several important features of the model. First, there are multiple interest rates: a short-term rate $\left(\mathrm{i}_{\mathrm{F}}\right)$, a deposit rate $\left(\mathrm{i}_{\mathrm{F}}-\mathrm{z}\right)$, a bank loan rate $\left(\mathrm{i}_{\mathrm{L}}=\right.$ $\left.[1+\mathrm{m}(\mathrm{L})]_{\mathrm{F}}+\mathrm{c}\right)$, and a long-term bond rate $\left(\mathrm{i}_{\mathrm{B}}\right)$. The short-term rate is exogenous and set by policy. The long-term bond rate is endogenous and determined by money supply as money demand conditions. The money supply is determined via bank lending in accordance with endogenous money theory: money demand depends on the state of liquidity preference (including expectations of future interest rates) in accordance with Keynes' theory. For instance, an increase in liquidity preference (the state of bearishness) shifts the money demand function down in the southeast panel, causing the bond rate to rise. An increase in expected future interest rates also increases money demand as wealth holders shift out of bonds to avoid capital losses. That causes bond prices to fall, raising the current bond interest rate.

Second, in this simplest of structuralist models, money supply and money demand are independent. Money supply is determined by the banking system, and money demand then causes interest rates to adjust so that agents hold the existing money balances. In the southeast quadrant, the money supply schedule is actually vertical, which looks a lot like Keynes's General Theory model except that the money supply is not exogenous.

Third, there are three arenas of policy concern. The first is setting the short term interest rate; the second is managing the loan market regarding its provision of bank credit and money creation; and the third is managing long term interest rates. That is a very different description of monetary policy than the neo-Keynesian model with interest rate targeting.

\section{REFINING THE STRUCTURALIST MODEL}

The above simple structuralist model can be modified to add complexity.

Make loan demand a positive function of the bond rate

In this case loan demand is given by

$$
\text { (21.1) } \mathrm{L}=\mathrm{L}\left(\mathrm{i}_{\mathrm{L}}, \mathrm{i}_{\mathrm{B}}, \mathrm{y}, \mathrm{A}\right) \quad \mathrm{L}_{\mathrm{iL}}<0, \mathrm{~L}_{\mathrm{iB}}<0, \mathrm{~L}_{\mathrm{y}-\mathrm{T}}>0, \mathrm{~L}_{\mathrm{A}}>0
$$

The logic behind this specification is bank loans and bonds represent alternative ways of financing business so that bond finance is a substitute for loan finance. A higher bond rate therefore increases loan demand, while a lower bond rate lowers loan demand.

This re-specification of loan demand changes the money supply process and eliminates independence of money supply and money demand. Instead, there is bi-directional causality between loan demand and money demand. ${ }^{7}$ As before, an increase in loan demand increases bank lending and the money supply. However,

\footnotetext{
${ }^{7}$ Pollin $(1991,2008)$ reports this pattern to interest rates and money supply - bank lending causality in his empirical critique of horizontalism - accommodationism.
} 
now, an increase in money demand increases the bond rate, thereby inducing an increase in loan demand that also increases bank lending and the money supply. The money supply remains endogenous, but it is no longer driven exclusively by loan demand. It is also affected by money demand.

This type of financial market inter-dependence connects the Post Keynesian structuralist theory of endogenous money with James Tobin's Yale School of monetary macroeconomics. Liquidity preference, the character of asset demands, and the degree of asset substitutability are all critical factors in determining financial market outcomes.

\section{Credit rationing}

A second modification is the introduction of credit rationing. As banks become loaned up and balance sheets become stressed, banks may vary lending standards to ration lending. In this case loan demand at the representative bank becomes:

(21.2) $\mathrm{L}=\theta(\mathrm{L} / \mathrm{E}, \mathrm{B} / \mathrm{L}, \ldots) \mathrm{L}\left(\mathrm{i}_{\mathrm{L}}, \mathrm{i}_{\mathrm{B}}, \mathrm{y}, \mathrm{A}\right)$

$$
0<\theta<1, \theta_{\mathrm{L} / \mathrm{E}}<0, \theta_{\mathrm{B} / \mathrm{L}}<0
$$

$\theta=$ loan rationing coefficient, $\mathrm{L} / \mathrm{E}=$ representative bank's loan-to-equity ratio, $\mathrm{B} / \mathrm{L}=$ representative bank's borrowed reserves-to-loan ratio. Increases in the loan-toequity ratio or borrowed reserves-to-loan ratio are indicative of bank balance sheet stress and induce a tightening of lending standards. Other factors may also affect $\theta$. In terms of Figure 6, an increase in the loan rationing coefficient shifts the effective loan demand to the left in the northwest panel. That reduces lending and deposit creation at the going interest rate, which shifts the money supply function left. ${ }^{8}$

In a more complicated disaggregated model there can be many types of borrower who are differentiated by credit risk. Rather than change loan mark-ups, banks may impose credit rationing by re-assigning borrowers across risk categories. Thus, when credit is tight, a greater proportion of borrowers may be classified as risky and charged a higher interest rate. The reverse holds when credit is easy. Such behavior will render total bank lending negatively correlated with credit rationing, and it will render the average loan rate positively correlated with credit rationing and negatively correlated with lending.

Endogenize the cost of funds to banks

A third possibility in a model with bank diversity is that individual banks confront different costs of wholesale funds, reflecting differences in financial strength across banks. In this case, the jth bank's cost of funds becomes

(28) $\mathrm{iF}, \mathrm{j}=\gamma(\mathrm{L} / \mathrm{Ej}, \mathrm{B} / \mathrm{Lj}) \mathrm{iF}$

$$
\gamma>1, \gamma \mathrm{L} / \mathrm{E}>0, \gamma \mathrm{B} / \mathrm{L}>0, \mathrm{j}=1, \ldots ., \mathrm{N}
$$

$\mathrm{iF}, \mathrm{j}=$ wholesale cost of funds to the jth bank, $\mathrm{L} / \mathrm{Ej}$, = loan-to-equity ratio of

\footnotetext{
${ }^{8}$ Credit rationing is inconsistent with the horizontalist/accommodationist approach. According to horizontalists, banks are never constrained by the supply of finance which is provided perfectly elastically by the central bank. Credit rationing due to financial congestion is therefore not an issue.
} 
the $\mathrm{jth}$ bank, $\mathrm{B} / \mathrm{Lj}=$ borrowed reserves-to-loans of the $\mathrm{jth}$ bank. As individual banks become more loaned-up and their balance sheets become more stressed, they must pay more to get financing in the wholesale money market.

For purposes of macroeconomic modelling, suppose the average bank is taken to be representative of the banking system. In that case, the average cost of funds to banks in the banking system will be a positive function of the average bank loan-to-equity ratio and the average borrowed reserves-to-loan ratio. The cost of funds to banks, and therefore the bank loan rate, will depend on the state of banks' balance sheets.

This type of balance sheet effect is an important analytical difference between the structuralist and accommodationist/horizontalist perspectives. Accommodationists view individual banks as financially unconstrained, the only constraint on banks being loan demand. Structuralists view banks as facing their own financial constraints which act as a form of finance supply constraint. Individual banks are constrained by the state of their balance sheets which impact their ability to get finance to back the loans they make.

There is much empirical microeconomic evidence for such constraints. Banks that are viewed by financial market participants as more risky must pay more to get money market finance. If money market participants are fearful of the quality of a bank's loan book, the bank will have to pay more to access money market finance. In extreme cases banks can be shut-out of the market as happened to Bear Stearns and Lehman Brothers in the financial crisis of 2008.

This type of financial constraint effect also explains why "Too Big To Fail” is viewed as a competitive distortion. TBTF banks get an implicit subsidy because money market lenders believe the central bank will always come to their rescue and are therefore willing to lend to TBTF banks at a lower rate. For TBTF banks $\gamma=1$ : for smaller banks $\gamma>1$. This type of effect is impossible in the accommodationist/horizontalist narrative in which all banks have unlimited access to money market finance at the same rate.

Analytically, the accommodationist/horizontalist account (Moore, 1988) conflates the "banking system" with "individual banks". The banking system is made up of individual banks. The system as a whole is financially unconstrained but individual banks are. The accommodationist/horizontalist approach commits the fallacy of division by assuming individual banks are the same as the banking system.

\section{Endogenize the central bank's policy behavior.}

Lastly, the central bank's policy interest rate can be endogenized to introduce macro structural effects. The simplest policy rule is to make the policy interest rate a positive function of the volume of lending or the money supply, as described earlier. More realistically, the policy rate will be a function of macroeconomic variables like the inflation rate and level of economic activity (Palley, 1996, 2013a).

Incorporating a policy reaction function has important implications for the 
money supply process. First, a "leaning against the wind" reaction function will impose constraints on the financial system so that the banking system does do not have a perfectly elastic loan supply function. Second, if individual banks know about the policy reaction function, they will adapt their behavior so as not to get caught short of liquid funds. This is a form of the Lucas critique (Lucas, 1976) applied to banks. The implication is that not only are banks financially constrained by the state of their own individual balance sheets, they are also financially constrained by the macroeconomic policy outlook which they take account of in making lending and asset allocation decisions. ${ }^{9}$

\section{ENDOGENOUS MONEY AND THE LM SCHEDULE}

The ISLM model used to be the analytical workhorse of Keynesian economics. However, it has been substantially abandoned, particularly because of dis-satisfaction with the LM schedule and theory of the money supply embedded in it. The above structuralist model can be used to properly derive the LM schedule for an endogenous money economy.

The derivation follows from Figure 6. The first thing to note is that there are a minimum of three interest rates in the financial sector, instead of one. The shortterm money market rate which is exogenously set by the monetary authority according to its policy reaction function; the loan interest rate which is determined by banks' mark-up over the short-term money market rate; and the long-term bond rate which is determined by money demand (i.e. liquidity preference). A second feature is the bank loan market, which is invisible in the conventional ISLM model, is central for a properly specified LM schedule as bank lending creates money.

For simplicity, let us assume that the short-term policy rate is exogenous and unresponsive to the level of economic activity. Additionally, assume the loan market rate is set according to a fixed mark-up that is unaffected by the level of lending. Now, consider the effect of an increase in the level of income on the financial sector equilibrium in Figure 6. Higher income shifts the loan demand function to the right, increasing bank lending and the money supply. It also increases money demand and shifts the money demand schedule to the right. The effect on the longterm bond rate is ambiguous and depends on the relative income elasticity of loan demand and money demand. If loan demand is more income elastic than money

\footnotetext{
${ }^{9}$ This macroeconomic financial constraint is another critique of horizontalism which reflects a fallacy of division within its thinking (Palley, 2013a). The fallacy of composition is the belief that the system is identical to the individual parts. The fallacy of division is the belief that the individual parts are a reflection of the system. Horizontalism falls prey to the fallacy of division by thinking because the central bank sets a fixed interest rate and a perfectly elastic supply of funds within the market period, banks act as if that is the permanent state of affairs and take no account of the possibility rates may be higher in future (i.e. next period).
} 
demand, the increase in income will generate a relatively larger increase in lending and the money supply, causing the bond rate to fall: the LM schedule will be negatively sloped. If loan demand is less income elastic than money demand, the increase in income will generate a relatively smaller increase in lending and the money supply, causing the bond rate to fall: the LM schedule will be positively sloped. These two possibilities are shown in Figure 7.

Figure 7: The LM schedule in an endogenous money system

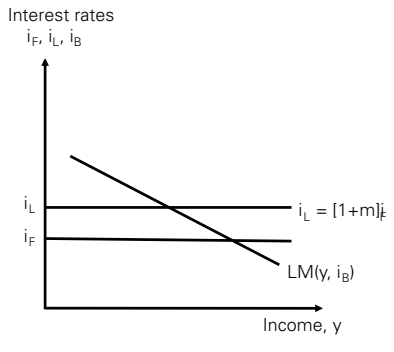

Case 1: loan demand more income elastic than money demand

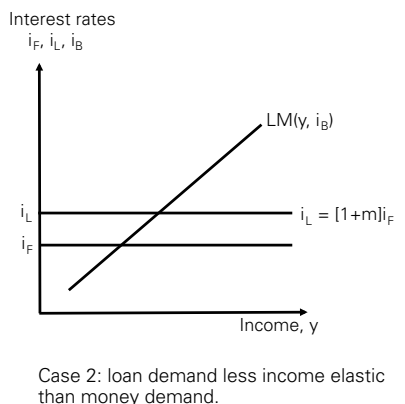

than money demand.

Now, consider the following experiments. An increase in loan demand increases the money supply and shifts the LM schedule down. An increase in money demand shifts the LM schedule up. An increase in the short-term policy interest rate shifts both the policy and loan rate schedules up. It also reduces loan demand which reduces the money supply, and increases money demand. These two changes cause the LM to shift up. If an IS schedule were added to close the model, the long bond rate would increase in response to a higher short term policy interest rate.

Comprehensively specifying the model economy requires taking full account of the central bank, the central government, and the private sector. That is an exercise for another occasion. The current purpose has been limited to show that the LM schedule is consistent with endogenous money; that the LM is not horizontal as often claimed; and that the LM can be positively or negatively sloped depending on the relative income elasticity of loan and money demand.

\section{SOME OBSERVATIONS ON INTEREST RATE POLICY IN AN ENDOGENOUS MONEY ECONOMY}

The last part of the paper discusses why endogenous money matters for interest rate policy. Inspection of Figure 6 shows interest rate policy can be thought of as operating in two arenas. Arena 1 concerns short-term interest rate policy (northwest quadrant) which directly impacts the bank credit market (northeast quadrant); arena 2 concerns long-term interest rate policy (southeast quadrant). 


\section{Short-term interest rate management: the new corridor model}

In the past, the short-term policy interest rate has been managed via open market operations using very short-term financial papers such as overnight repurchase agreements. Now, central banks are introducing what can be called the "corridor" model (Kahn, 2010; Lavoie, 2010).

The corridor model is illustrated in Figure 8. The central bank picks a triple consisting of target short-term rate, a short-term central bank lending rate and a short-term central bank deposit rate. The short-term central bank lending rate is slightly above the target rate, and the short-term central bank deposit rate is slightly below the target rate. The central bank is then willing to lend unlimited quantities at the lending rate, and take unlimited quantities of deposits at the deposit rate. The actual rate fluctuates between the boundaries. If there is an aggregate shortage of reserves, the banking system will borrow at $i_{F, L E N D}$. If there is an aggregate surplus of reserves, the banking system will deposit at $i_{F, D E P O S I T}$.

\section{Figure 8: The "corridor" model of short-term interest rate management}

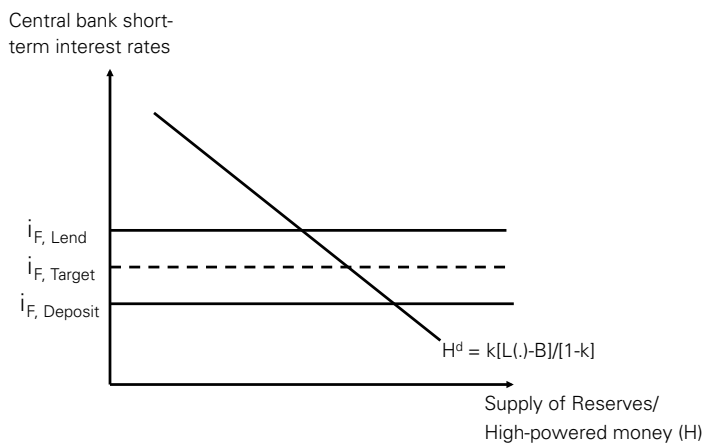

\section{Long-term interest rate policy}

Historically, central banks have not done much direct intervention regarding long rates. On a few occasions, there have been "operation twist" interventions whereby central banks have engaged in sterilized buys of long-term bonds matched by sales of short-term bonds. The aim has been to twist the term structure of interest rates by lowering long rates and increasing short rates.

Instead of direct intervention regarding long-term interest rates, the standard strategy regarding long rates has been to manage the short-term rate and combine that with a commitment to low inflation, thereby guiding expectations of future short-term rates. In other words, policymakers have sought to influence long-term rates via the expectations theory of the term structure of interest rates. Today, they are still doing that, but have now added the extra tool of "forward guidance" whereby they give predictions of what the future short term policy rate will be. 
That is supposed to strengthen policymakers' ability to move market expectations of future short term rates, thereby strengthening policy influence over the term structure.

Quantitative easing $(\mathrm{QE})$ has introduced a new dimension and it looks like it may be here to stay, with central banks becoming permanent buyers and sellers of longer term papers on a regular and significant basis. Under QE, most of the purchases have been longer term government bonds, but banks have also bought mortgage backed securities to help the housing sector.

Central bank purchases of long-term bonds raises the questions of what are the mechanics of these purchases and what are the implications for the money supply. Figure 6 helps answer these questions. The initial central bank purchase involves a swap of money $(\Delta \mathrm{M}>0)$ for bonds $(\Delta \mathrm{B}<0)$ so that the non-bank public's money holdings increase and bond holdings decrease. The central bank pays for the bonds by crediting banks with reserves. If borrowed reserves are positive, banks use some of the new reserves to back the new deposits and the rest to pay back borrowed reserves. Required reserves increase $(\Delta R R>0)$, borrowed reserves decrease $(\Delta \mathrm{BR}<0)$ and the high-powered money supply increases $(\Delta \mathrm{H}>0)$. If banks have excess reserves, banks use some of the new reserves $(\Delta H>0)$ as required reserves $(\Delta \mathrm{RR}>0)$ and the rest they add to excess reserves $(\Delta \mathrm{ER}>0)$. Central bank sales of bonds have the opposite signed effects.

There are two features to note. First, the monetary authority has an effect on the money supply by destroying or creating bank deposits. This is very similar to traditional exogenous money theory. It shows that central banks can directly impact the money supply and that the money supply is not exclusively determined by loan demand, contrary to the claims of Post-Keynesian horizontalists and accommodationists. Second, the long term interest rate is endogenous and determined by liquidity preference, and the effects of $\mathrm{QE}$ on asset prices and long bond interest rates work via the traditional Keynesian liquidity preference channel.

With regard to the merits of QE-like policies, I have argued this is a good development (Palley, 2013b, p. 636-637). If policymakers want to influence longer term interest rates, they should do it directly. Managing long-term rates via shortterm rates and the term structure of interest rates is sub-optimal. That is because the term structure management channel is subject to interference by noise associated market misunderstandings, volatile and uncertain market expectations and fluctuations in liquidity preference. That makes it preferable to directly manage the long-term rate.

Lastly, there is a connection between long-term bond purchases and the corridor model. Long-term bond purchases inject liquidity into the banking system. If the banking system has a borrowed reserve position, some of that liquidity will be used to repay borrowed reserves from the central bank. Conversely, if the banking system has an excess reserve position, some of that liquidity will be deposited with the central bank to earn interest. 


\section{CONCLUSION: WANTED, A RECONSTRUCTED \\ ISLM MODEL WITH ENDOGENOUS MONEY}

This paper has presented the Post Keynesian theory of endogenous money supply, which is fundamentally different from the conventional approach to money supply determination. Money is at the center of macroeconomics, which makes understanding the determination of the money supply a critical component of macroeconomic theory. The conventional approach relies on the money multiplier and bank lending is completely invisible and passive. The Post Keynesian approach discards the money multiplier and focuses on bank lending which drives money creation. The paper was supportive of the structuralist version of Post Keynesian theory as it retains Keynes' liquidity preference theory of long term interest rates and also recognizes banks are subject to financial constraints that limit their lending activities.

A major reason the ISLM model fell out of favor was its faulty treatment of the money supply and the absence of credit, both of which afflicted the LM schedule. Remedying those failings in the LM schedule has been a long-standing necessary prelude for reconstructing the ISLM model. The structuralist model provides a micro-founded theory of the endogenous money supply which can be used to derive the LM schedule for an endogenous money economy. The endogenous money LM schedule can be positively or negatively sloped, depending on the relative income elasticities of bank loan demand and money demand. The next step is to develop a fully reconstructed ISLM model with the full set of stock - flow consistent relations between sectors.

\section{REFERENCES}

Coghlan, R. (1978), “A new view of money”. Lloyds Bank Review, 129 (July), 12 - 28.

Kahn, G.A. (2010), “Monetary policy under a corridor operating framework”. Economic Review, Kansas City Federal Reserve Bank, fourth quarter, 5 - 34.

Kaldor, N. (1970), “The new monetarism”. Lloyds Bank Review, 97: 1-7.

Kaldor, N. (1982), The Scourge of Monetarism. Oxford: Oxford University Press.

Keynes, J.M. (1930), A Treatise on Money. London: Macmillan.

Keynes, J.M. (1936), The General Theory of Employment, Interest, and Money. London: Macmillan.

Lavoie, M. (1996), "Horizontalism, structuralism, liquidity preference and the principle of increasing risk”. Scottish Journal of Political Economy, 43 (August), 275-300.

Lavoie, M. (2006), "Endogenous money: Accommodationist”, In P.Arestis and M.Sawyer (eds), A Handbook of Alternative Monetary Economics. Cheltenham, UK: Edward Elgar, 17-34.

Lavoie, M. (2010), "Changes in central bank procedures during the sub-prime crisis and their repercussions on monetary theory". Levy Economics Institute at Bard College, Working Paper No. 606.

Lucas, R.E., Jr. (1976). “Econometric policy evaluation: A Critique”. In K.Brunner and A.H.Meltzer (eds.), The Phillips Curve and Labor Markets, Amsterdam: North-Holland, 19-46.

Moore, B.J. (1988) Horizontalists and Verticalists: The Macroeconomics of Credit Money. Cambridge: Cambridge University Press.

Palley, T.I. (1987/88), "Bank lending, discount window borrowing, and the endogenous money supply: A theoretical framework”. Journal of Post Keynesian Economics, X(2), 282-303. 
Palley, T.I. (1991), “The endogenous money supply: Consensus and disagreement”. Journal of Post Keynesian Economics, 13 (Spring), 397-403.

Palley, T.I. (1993), “Milton Friedman and the monetarist counter-revolution: A reappraisal”. Eastern Economic Journal, Winter, 71-82.

Palley, T.I. (1994), “Competing views of the money supply process: Theory and evidence”. Metroeconomica, 45 (1), 67-88.

Palley, T.I. (1996), “Accommodationism versus structuralism: Time for an accommodation”. Journal of Post Keynesian Economics, 18 (Summer), 585-94.

Palley, T.I. (1998) "The twin circuits: Aggregate demand and the expenditure multiplier in a monetary economy”. Review of Radical Political Economics, 30 (September), 95-104.

Palley, T.I. (2013a), "Horizontalists, verticalists, and structuralists: the theory of endogenous money reassessed". Review of Keynesian Economics, 1 (4), 406-424.

Palley, T.I. (2013b), "Monetary policy and central banking after the crisis: The implications of rethinking macroeconomic theory". In Gerald Epstein and Martin Wolfson, eds. The Handbook on Political Economy of Financial Crises. Oxford: Oxford University Press, Chapter 31, 624-643.

Palley, T.I. (2014a) "Milton Friedman's economics and political economy: an old Keynesian critique". Working Paper 134, IMK/Macroeconomic Policy Institute, Dusseldorf, Germany, July.

Palley, T.I. (2014b), "Errata in 'Horizontalists, verticalists, and structuralists: the theory of endogenous money reassessed'. Review of Keynesian Economics, 1 (4), 406-424.

Palley, T.I. (2014c), "Monetary policy at the zero lower bound and after: A reassessment of quantitative easing and critique of the Federal Reserve's proposed exit strategy". Metroeconomica, online July 15 .

Pollin, R. (1991), “Two theories of money supply endogeneity: Some empirical evidence”. Journal of Post Keynesian Economics, 13, 366-96.

Pollin, R. (2008), “Considerations on interest rate exogeneity: To what extent does the market determine rates?”. Working Paper 177, Political Economy Research Institute, University of Massachusetts, Amherst, MA, August.

Poole, W. (1970), “Optimal monetary policy instruments in a simple stochastic macro model”. Quarterly Journal of Economics, 84, $197-216$.

Sargent, T.J., and N.Wallace (1975), "Rational expectations, the optimal monetary instrument, and the optimal money supply rule”. Journal of Political Economy, 83, 241-54. 